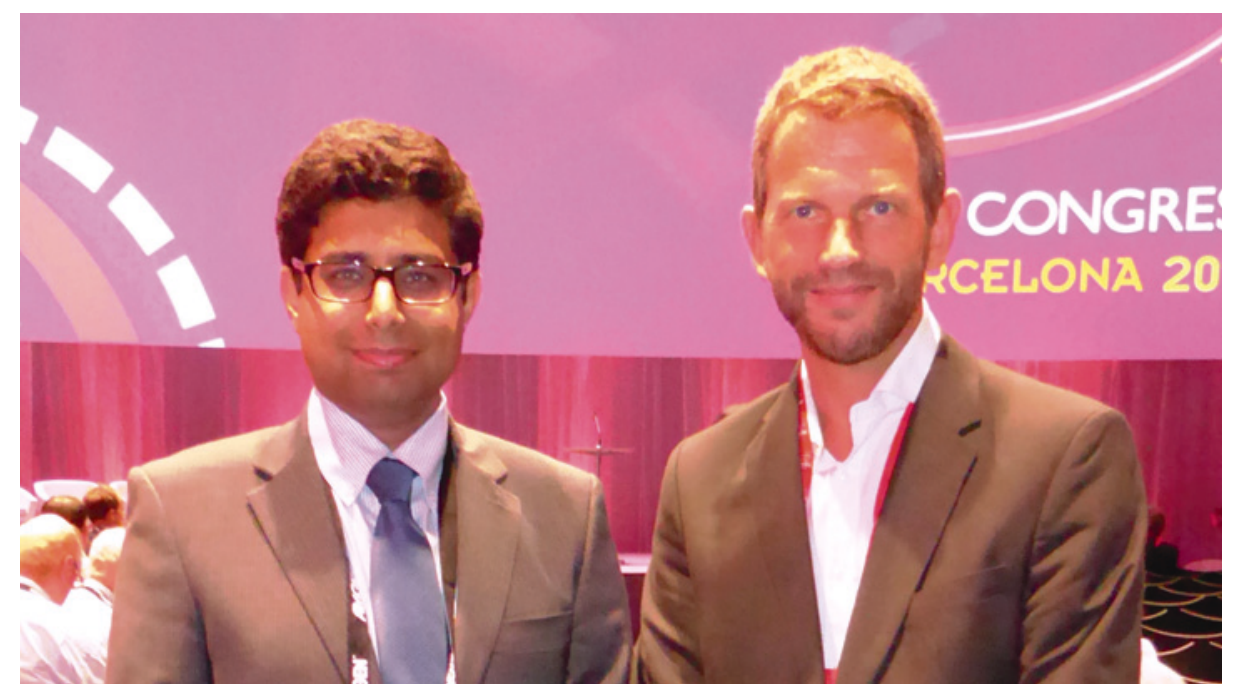

Førsteforfatter Dipak Kotecha og medforfatter Thomas von Lueder under presentasjon av studien ved årets kongress i European Society of Cardiology. Foto: privat

\section{Betablokkere til hjertesviktpasienter med atrieflimmer?}

Behandling med betablokkere gir ikke færre dødsfall hos hjertesviktpasienter med atrieflimmer sammenliknet med placebo.

Betablokkere er en viktig del av hjertesviktbehandlingen, men hvordan er effekten ved samtidig atrieflimmer? En internasjonal forskergruppe, med deltakelse fra Oslo universitetssykehus, har nylig undersøkt dette (1). De ekstraherte individuelle pasientdata fra ti store studier med til sammen over 18000 hjertesviktpasienter, som alle hadde blitt randomisert til behandling med betablokkere eller placebo. $76 \%$ av pasientene hadde sinusrytme og $17 \%$ hadde atrieflimmer ved inklusjon i studien.

Etter 1,5 års oppfølging var $16 \%$ av pasientene med sinusrytme og $21 \%$ av dem med atrieflimmer, døde. Hasardratio var på henholdsvis 0,73 (95\% KI $0,67-0,80)$ og $0,97(95 \%$ KI 0,83-1,14).

- Denne metaanalysen dokumenterer, som mindre studier har gitt mistanke om, at det bare er hjertesviktpasienter med sinusrytme som har effekt av betablokkere, sier medforfatter Thomas von Lueder, som er kardiolog ved Oslo universitetssykehus, Ullevål.

- Gjeldende retningslinjer for hjertesviktbehandling anbefaler betablokkere uansett hjerterytme, men denne studien kan komme til å føre til endringer. Hvilket legemiddel som egner seg best til frekvenskontroll hos hjertesviktpasienter med atrieflimmer bør undersøkes i prospektive studier, sier von Lueder.

\section{Internasjonalt samarbeid om hjertesvikt}

Beta-Blockers in Heart Failure Collabora-

tive Group ble stiftet i 2008 og ledes av
Ordforklaringer

Hjertesvikt: En tilstand der hjertets pumpeevne og/eller fylningsevne er svekket. Dette fører til symptomer som tung pust, utmattelse og væskeopphopning i kroppen. De vanligste årsakene er hjerteinfarkt, kransåresykdom, høyt blodtrykk, klaffefeil og kardiomyopatier. Hjertesvikt forekommer hos 1-3\% av befolkningen og er særlig vanlig hos eldre mennesker. Sykdommen deles inn etter hvilket av hovedkamrene som svikter (venstre, høyre eller biventrikulært), eller om det er systolisk eller diastolisk funksjon som er redusert. Prognosen ved hjertesvikt er alvorlig, med over $50 \%$ dødelighet etter fem år.

Betablokkere: En gruppe legemidler som brukes ved ulike hjerte- og karsykdommer fremfor alt hjertesvikt, hjerteinfarkt, høyt blodtrykk og hjerterytmeforstyrrelser. De hemmer virkningen av stresshormoner som adrenalin og noradrenalin ved å blokkere reseptorer i det sympatiske nervesystemet. Tidligere var behandling med betablokkere kontraindisert ved hjertesvikt på grunn av potensialet for å forverre sykdommen. Studier fra midten av $1990-$ årene viste imidlertid positive effekter på sykelighet og dødelighet ved denne tilstanden. Metoprolol, bisoprolol og karvedilol er de mest brukte betablokkerne ved hjertesvikt i Norge.

Atrieflimmer: Også kalt forkammerflimmer, forekommer hos 1-2\% av den norske befolkningen. Det er definert som uregelmessig aktivitet i forkamrene med en frekvens på 300-600 slag i minuttet. Fordi atrioventrikulærknuten blokkerer de fleste av impulsene, vil hovedkamrene som regel slå mellom 100-150 ganger i minuttet. Atrieflimmer gir økt risiko for hjerneslag og død og krever ofte forebyggende behandling med blodfortynnende medisiner. Opptil 1 av 5 pasienter med hjertesvikt har samtidig atrieflimmer.

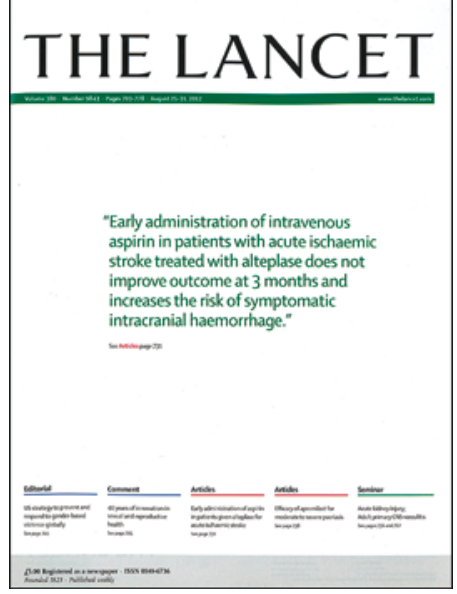

Lise Mørkved Helsingen

Tidsskriftet

\section{Litteratur}

1. Kotecha D, Holmes J, Krum H et al. Efficacy of $\beta$ blockers in patients with heart failure plus atrial fibrillation: an individual-patient data meta-analysis. Lancet 2014; e-publisert 2.9.2014.

dr. Dipak Kotecha fra Birmingham. Gruppen fra ledende hjertesviktmiljøer samt Douglas professor i medisinsk tatistere. Altman 1.a. kjent som grunnleggeren skrevet på vegne av hele gruppen, med 16 ciency Bisoprolol Study (CIBIS-I og CIBISI) og var eneste norske medforfatter. Han ferdiostilt våren 2014 og vil kunne belyse flere spørsmål rundt betablokkere ved hjertesvikt.
Resultatene fra analysen ble lagt frem under årsmøtet til European Society of Cardiology i Barcelona og samtidig publisert online i det prestisjetunge tidsskriftet The Lancet 2.9. 2014 